\title{
Development and use of a micro haemagglutination inhibition (HAI) technique, based on Hepatest, for the detection and quantitation of hepatitis B surface antibody (Anti-HB s $_{\text {) in blood donors }}$
}

\author{
I. C. WISEMAN ${ }^{1}$ \\ From the Regional Transfusion Centre, Longley Lane, Sheffield S5 7JN
}

SUMMARY A simple micro haemagglutination inhibition technique, based on Hepatest (Wellcome Reagents Limited), is described. Its application in the screening of blood donors is shown, and it $\overrightarrow{\mathrm{s}}_{\text {. }}$ sensitivity is discussed in two forms of usage and also when compared to the previous immunoelectroosmophoresis technique used in this centre.

Previous workers have developed HA/HAI test systems for the detection of Anti-HB $\mathrm{H}_{\mathbf{s}}$ based on coated erythrocytes prepared in their own laboratories (Pert and Verch, 1975; Hopkins and Das, 1973). The use of these preparations is not always possible in other centres. This paper describes a simple micro haemagglutination inhibition (HAI) technique based on Hepatest (Wellcome Reagents Limited). The small volume of commercial reagent required for the test gives an inexpensive screening technique of high sensitivity, with an easily readable result available in $1 \frac{1}{2}$ hours.

\section{Materials}

Hepatest Kit (Wellcome Reagents Limited).

Terasaki plate, and inclined plate stand.

SMI Micropettor (Dynatech).

Hamilton repeating dispenser (V. A. Howe).

Pasteur dropping pipettes, calibrated to deliver $0.025 \mathrm{ml}$.

Serum from a known carrier of hepatitis B surface antigen $\left(\mathrm{HB}_{\mathrm{s}} \mathrm{Ag}\right)$.

Working buffer.

\section{Method}

PRINCIPLE

To serum under test is added a measured amount of a previously standardised $\mathrm{HB}_{\mathbf{s}} \mathrm{Ag}$ positive serum diluted in working buffer.

1 Present address: Department of Haematology, The Jessop Hospital for Women, Sheffield 3.

Received for publication 24 May 1976
This mixture is allowed to stand at room temperace ture for $\mathbf{3 0}$ minutes. It is then tested for reactivity against Hepatest test and control cells in the Terae saki plate test previously described (Wiseman 1976).

Presumptive Anti-HB sositive sera are furthe摸 tested by titration for the inhibition of two antigen $\$$ and confirmed by radioimmunoassay (RIA).

High-titre antibody-positive donor plasma then separated and sent routinely to the Lister Institute for processing into hepatitis $B$ antibod immunoglobulin (HBIG) for prophylaxis.

\section{TECHNIQUE}

\section{Standardisation of antigen}

A previously detected $\mathrm{HB}_{\mathrm{S}} \mathrm{Ag}$ positive blood dono offered his cooperation and was first bled fo? testing purposes. His serum had previously been used as an IEOP screening reagent because of it availability and broad spectrum of reactivity againsts a panel of Anti-HB B $_{\text {s }}$ positive sera, when character ised by Dr Bradstreet at the Standards Laboratory Colindale, London.

A full donation was collected from this dono into a dry bottle, and the serum was separated aseptically, dispensed into $1 \mathrm{ml}$ aliquots, and store in liquid nitrogen. This storage method was chosen after testing, to retain the full antigenic potency ofo the serum for as long a period of time as possible.

With the knowledge of the titre of this $\mathrm{HB}_{\mathbf{S}} \mathrm{A} \&$ by Hepatest, and also of the dilution factors in $\bar{Q}$ volved in the HAI technique, suitable dilutions were prepared and chequerboard titrations performed 
giving inhibition of several examples of Anti-HB, tests being performed against both test and control cells.

The examples of Anti-HB $\mathrm{B}_{\mathrm{s}}$ were selected to cover a range of IEOP titres from neat to 1 in 8 . The final concentration of $\mathrm{HB}_{\mathrm{s}} \mathrm{Ag}$ was then adjusted according to the titration results to give an inhibition titre of at least 1 in 16 against test cells in the case of the weakest Anti-HB positive serum, and a negative reaction against control cells.

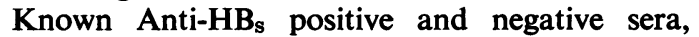
including Colindale Quality Control panels B and $\mathrm{C}$, were then tested neat and at dilutions of 1 in 10 and 1 in 20. This was done to confirm that the $\mathrm{HB}_{\mathrm{B}} \mathrm{Ag}$ dilution selected was capable of detecting

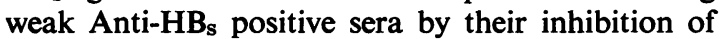
the agglutination of test cells, yet producing an easily visible agglutination pattern with test cells in the case of an Anti-HB negative serum (see Fig. 1).

The $\mathrm{HB}_{\mathrm{s}} \mathrm{Ag}$ used, 'OAT', had an optimum dilution of 1 in 500 in working buffer, and this was made up in $25 \mathrm{ml}$ volumes from the preserved serum and stored at $-40^{\circ} \mathrm{C}$ for up to one week before use.

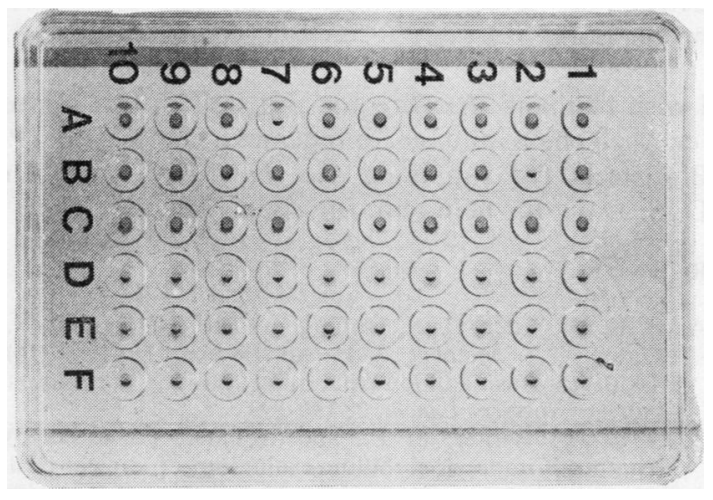

Fig. 1 Thirty sera screened against test cells (rows $A$, $B$, and $C$ ) and against control cells (rows $D, E$, and $F$ ). Screen test Anti-HBs positive sera are seen in wells $A 7, B 2$, and $C 6$.

\section{Screening methods}

(a) The racks of 30 donor sera are pooled to produce three pools of 10 sera per rack.

From each well-mixed pool, 1 drop, ie, $0.025 \mathrm{ml}$, is pipetted into a Taylor tube $(50 \times 10 \mathrm{~mm})$. To this is added 2 drops, ie, $0.050 \mathrm{ml}$, of the working $\mathrm{HB}_{\mathbf{B}} \mathrm{Ag}$ dilution; the tube is mixed and allowed to stand at room temperature for $\mathbf{3 0}$ minutes.

Eight microlitres of each dilution is then pipetted in duplicate into two wells of a Terasaki plate. After the 30 serum dilutions have been pipetted out, $4 \mu \mathrm{l}$ of test cells is added to one set of wells, and $4 \mu \mathrm{l}$ of control cells to the other.

The plates are then inclined as previously described, and the results are read after one hour (see Fig. 1).

(b) All donor sera are tested singly instead of in pools, otherwise the technique is identical.

\section{CONTROLS}

With each batch of tests, a known Anti-HB s positive serum is tested neat, and at dilutions of 1 in 10 and 1 in 20 . For the tests to be valid, there must be no reaction against either test cells or control cells in any of these six wells.

The potency of the test cells is checked daily by using the Wellcome $\mathrm{HB}_{\mathrm{S}} \mathrm{Ag}$ positive control serum supplied with the Test $\mathrm{Kit}$ in the $\mathrm{HB}_{\mathrm{S}} \mathrm{Ag}$ screening test as previously described.

\section{Results}

The results are read macroscopically over a diffused light source. A serum, or pool of sera, is presumed to be Anti-HB positive if there is no agglutination of test cells or control cells. A negative result for Anti-HB $_{\mathbf{s}}$ is shown by agglutination of the test cells and no agglutination of the control cells.

If any serum, or pool of sera, agglutinates the control cells, then the test is invalid and must be repeated after the serum has been absorbed with control cells.

\section{Confirmatory testing and quantitation}

If a pool of serum gives a presumptive Anti-HB positive reaction in the screening test, the component sera in that pool are further tested singly to establish which one or more sera are Anti-HB positive.

The next stage of the confirmatory testing is then performed on serum taken direct from the master clotted sample to ensure correct sample identity.

Doubling dilutions from neat to 1 in 512 are prepared in group $\mathrm{AB}$ serum, negative for $\mathrm{HB}_{\mathbf{s}} \mathrm{Ag}$ and Anti-HBs.

To duplicate sets of these dilutions are added two different $\mathbf{H B}_{\mathrm{s}} \mathrm{Ag}$ positive sera at their respective working dilutions.

Each of these dilutions is then tested with test and control cells in Terasaki plates, and the titre of the

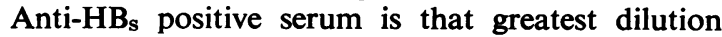
showing inhibition of agglutination of the test cells, the control cells not being agglutinated in any dilution (see Fig. 2).

Thus an inhibition titre against two different 


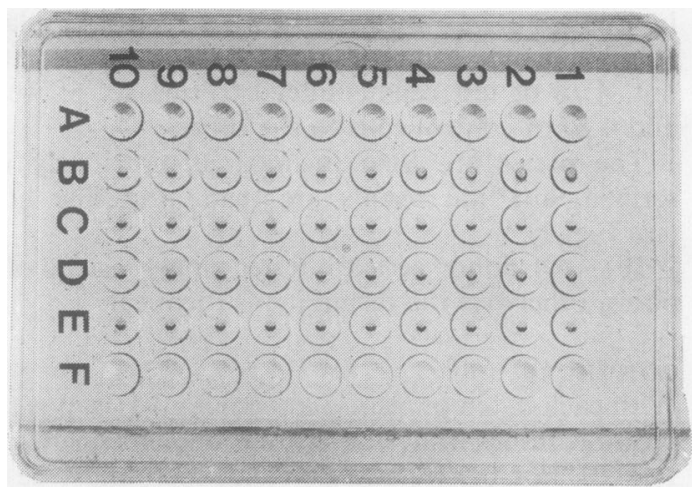

Fig. 2 Titration of a screen test Anti-HB $B_{8}$ positive serum. Rows $B$ and $C$ are titrations against $H B_{8} A g(I)$, row $B$ test cells, row $C$ control cells. Inhibition titre $1: 32$.

Rows $D$ and $E$ are titrations against $H B_{8} A g(I I)$, row $D$ test cells, row E control cells. Inhibition titre 1:128.

Table Blood donor screening for Anti-HB

\begin{tabular}{|c|c|c|c|}
\hline Period & $\begin{array}{l}\text { Type of } \\
\text { testing }\end{array}$ & Number tested & $\begin{array}{l}\text { Anti-HB, } \\
\text { frequency }\end{array}$ \\
\hline $\begin{array}{l}1 \text { Jan '73- } \\
31 \text { Dec '74 }\end{array}$ & $\begin{array}{l}\text { Single dona- } \\
\text { tion testing by } \\
\text { IEOP }\end{array}$ & 229856 & $1 \times 4721$ \\
\hline $\begin{array}{l}1 \text { Jan '75- } \\
31 \text { Mar '75 }\end{array}$ & $\begin{array}{l}\text { Single dona- } \\
\text { tion testing by } \\
\text { IEOP }\end{array}$ & 29740 & $1 \times 4248$ \\
\hline $\begin{array}{l}3 \text { Nov'75- } \\
5 \text { Apr'76 }\end{array}$ & $\begin{array}{l}\text { Micro HAI } \\
\text { testing of } \\
\text { pools }\end{array}$ & 54260 & $1 \times 2583$ \\
\hline $\begin{array}{l}26 \text { Jan '76- } \\
5 \text { Apr '76 }\end{array}$ & $\begin{array}{l}\text { Micro HAI } \\
\text { testing of } \\
\text { single dona- } \\
\text { tions }\end{array}$ & 2480 & $1 \times 413$ \\
\hline
\end{tabular}

examples of $\mathrm{HB}_{\mathrm{s}} \mathrm{Ag}$ can be obtained in the case of a genuine Anti-HB $\mathrm{B}_{\text {s }}$ positive donor.

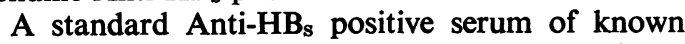
potency, previously tested by the Lister Institute,

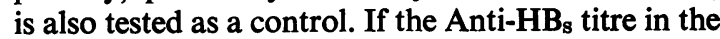
donor serum is as great as or greater than the control, then the donor plasma is judged to be suitable for HBIG production. The plasma is then separated and sent to the Lister Institute for processing.

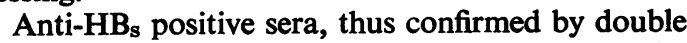
titration, are then sent for final confirmation by RIA testing to Dr Dane, Middlesex Hospital Medical School, London.

\section{Discussion}

From the Table it is apparent that this method of HAI is, at best, about 10 times as sensitive as
IEOP for the detection of Anti-HB in the Tren? Regional Health Authority area.

It is interesting to note that in the series of $2480 \%$ donations tested, none of the six Anti-HB positive sera detected was of sufficient titre to be positive in the pool test.

However, while in the past it has been suggested that Anti-HB s positive donors be excluded (Lehmanţ and Schlaak, 1975; Renton and Wadsworth, 1975a and b), there has more recently been an increasing. weight of opinion to suggest that such action is unjustified (De La Concha et al., 1974; Aach et al 요 1974; Fiedler, 1975; International Forum 1975).

The prophylactic value of HBIG is now welit recognised (Szmuness et al., 1974; Seef et al., 1975; Grady and Lee, 1975; Prince et al., 1975; Redekeig et al., 1975; Alter et al., 1975; British Medicab Journal, 1976) so until the development of a safe and effective vaccine there will be a demand for this form of prophylaxis, and already broader usê of HBIG is envisaged to protect such persons as the spouses of $\mathbf{H B}_{\mathrm{s}} \mathrm{Ag}$ carriers (Redeker et al. 1975).

There is, therefore, a place for a simple procedure to detect and quantitate Anti-HB of this technique is that its sensitivity can be set tQ detect only levels of Anti-HB suitable for HBIG production.

I wish to thank the Director and staff of this centre for their help and encouragement, Dr C. M. PO Bradstreet for supplying the panel sera, and $D \vec{F}$ D. S. Dane for help with the confirmatory testing.

\section{References}

Aach, R. D., Alter, H. J., Hollinger, F. B., Holland, P. V윰 Lander, J. J., Melnick, J. L., and Weiler, J. M. (1974). Risk of transfusing blood containing antibody to hepatitis B surface antigen. Lancet, 2, 190-193.

Alter, H. J., Barker, L. F., and Holland, P. V. $(1975)$ Hepatitis B immune globulin: evaluation of clinical triaf and rationale for usage. New England Journal of Medicines 293, 1093-1094.

British Medical Journal (1976). High-titre hepatitis B immuneglobulin (Editorial). British Medical Journal, 1, 241-242. N

De La Concha, E. G., De Los Rios, J. E., Masllorens, F. O., and Avendaño, L. H. (1974). Immunity to hepatitis-B in a haemodialysis unit (Letter). Lancet, $2,461$.

Fiedler, H. (1975). Risk of transfusing blood containing anti-HBs. (Letter). Lancet, 1, 341.

Grady, G. F., and Lee, V. A. (1975). Hepatitis B immuњe globulin-prevention of hepatitis from accidental exposure among medical personnel. New England Journal of Medicine, 293, 1067-1070.

Hopkins, R., and Das, P. C. (1973). A tanned cell haemag glutination test for the detection of hepatitis-associated antigen (Au Ag) and antibody (Anti-Au). British Journg of Haematology, 25, 619-629.

International Forum (1975). Does blood with antibodies against hepatitis B carry an increased risk to transmit hepatitis? Vox Sanguinis, 28, 460-467. 
Lehmann, H., and Schlaak, M. (1975). Is blood containing anti-HB $\mathrm{B}_{\mathrm{s}}$ infective? (Letter). Lancet, $1,1036$.

Pert, J. H., and Verch, R. L. (1975). An immune hemagglutination procedure with very high sensitivity applied to the detection of hepatitis B antibody and antigen and immune complex. Vox Sanguinis, 29, 157-176.

Prince, A. M., Szmuness, W., Mann, M. K., Vyas, G. N., Grady, G. F., Shapiro, F. L., Suki, W. N., Friedman, E. A., and Stenzel, K. H. (1975). Hepatitis B "immune" globulin: effectiveness in prevention of dialysis-associated hepatitis. New England Journal of Medicine, 293, 10631067.

Redeker, A. G., Mosley, J. W., Gocke, D. J., McKee, A. P., and Pollack, W. (1975). Hepatitis B immune globulin as a prophylactic measure for spouses exposed to acute type
B hepatitis. New England Journal of Medicine, 293, 1055-1059.

Renton, P. H., and Wadsworth, L. D. (1975). Infectivity of blood containing hepatitis-B antibody (Letters). Lancet, 1, (a) 528-529, (b) 746-747.

Seef, L. B. et al. (1975). Efficacy of hepatitis B immune serum globulin after accidental exposure. Lancet, 2, 939941.

Szmuness, W., Prince, A. M., Hoofnagle, J. H., Ribot, S. and Jacobs, M. J. (1974). Effectiveness of hepatitis-B immune globulin in haemodialysis patients (Letter). Lancet, 2, 1512-1513.

Wiseman, I. C. (1976). A modification of Hepatest, using the Terasaki plate, for the detection of $\mathrm{HB}_{\mathbf{8}} \mathrm{Ag}$ in blood donors. Journal of Clinical Pathology, 29, 264-266. 